ISSN 0449-3060

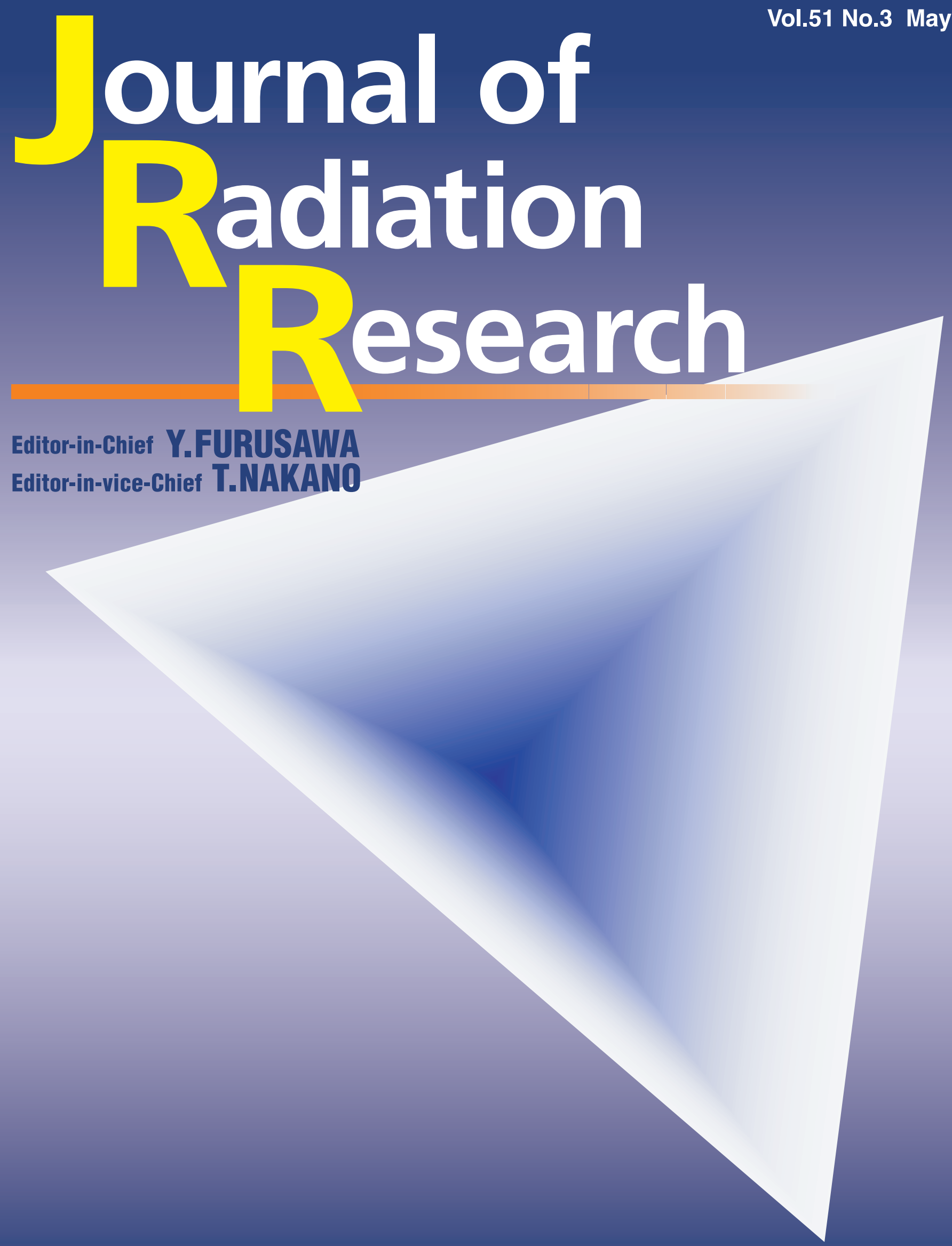

THE JAPAN RADIATION RESEARCH SOCIETY and JAPANESE SOCIETY FOR THERAPEUTIC RADIOLOGY AND ONCOLOGY 


\title{
Journal of Radiation Research
}

\author{
An Official Journal of The Japan Radiation Research Society and \\ Japanese Society for Therapeutic Radiology and Oncology
}

\author{
Volume 51, Number 3, May 2010 \\ Copyright (C) 2010 by The Japan Radiation Research Editorial Committee \\ All rights reserved
}

\author{
Editorial Office \\ c/o Medical Supply Japan Co., Ltd. \\ Natsume Bldg 3F, 2-18-6, Yushima Bunkyo-ku, \\ Tokyo, 113-0034, Japan \\ Tel; +81-3-3818-2176, Fax; +81-3-3818-2209 \\ jrroffice@nirs.go.jp / /jrred@me.com
}

Cover of the journal:

The triangle represents the three concepts included in the following sentences, the atomic energy basic law, chapter \#1 and article \#2 of Japan. The law reads "the research, development and utilization of atomic energy shall be limited to peaceful purpose, aimed at ensuring safety and performed independently under democratic management, the results there from shall be made public to contribute to international cooperation". The cover has been designed and used under the concept from the first issue in 1960, and renewed after 2002. 


\title{
JOURNAL OF RADIATION RESEARCH
}

June 2009

\author{
Editorial Board
}

Editor-in-Chief: Furusawa, Yoshiya

Editor-in-Vice-Chief: Nakano, Takashi

Managing Editors:

Ando, Koichi
Anzai, Kazunori
Fukumoto, Manabu
Kagami, Yoshikazu
Kamada, Tadashi

Matsumoto, Hideki

Sakai, Kazuo

Matsumoto, Yoshihisa

Sasai, Keisuke

Mitsuhashi, Norio

Shibuya, Hitoshi

Miura, Masahiko

Nakamura, Nori

Takatsuji, Toshihiro

\section{Associate Editors:}

Akiba, Suminori

Cui, Xing

Harima, Yoko

Hasegawa, Masatoshi

Hoshi, Masaharu

Hosoi, Yoshio

Ide, Hiroshi

Imai, Takashi

Inanami, Osamu

Ishizaki, Kanji

Kanai, Tatsuaki

Koana, Takao

Kobayashi, Junya

Kobayashi, Katsumi

Kobayashi, Yasuhiko

Kodama, Seiji

Kondo, Takashi

Kubota, Nobuo

Masunaga, Shin-ichiro

Mitsumori, Michihide

Miyakoshi, Jynji

Mizuno, Hideyuki

Nagata, Yasushi

Narita, Yuichiro

Niwa, Ohtsura

Oguchi, Hiroshi

Oguchi, Masahiko

Ohnishi, Ken

Onizuka, Masahiko

Ono, Tetsuya

Oya, Natsuo

Sakurai, Hideyuki
Shibamoto, Yuta

Shigematsu, Naoyuki

Shimada, Yoshiya

Suzuki, Gen

Suzuki, Keiji

Takahashi, Akihisa

Takahashi, Takeo

Tanaka, Atsushi

Tauchi, Hiroshi

Terahara, Atsuro

Todo, Takeshi

Tomita, Masanori

Uno, Takashi

Wang, Bing

Watanabe, Masami

Yoshioka, Yasuo

\section{Foreign Associate Editors:}

$\begin{array}{ll}\text { Azzam, Edouard } & \text { (USA) } \\ \text { Blakely, Eleanor A. } & \text { (USA) } \\ \text { Brahme Anders } & \text { (Sweden) } \\ \text { Chen, David } & \text { (USA) } \\ \text { Cho, Chul-Koo } & \text { (Korea) } \\ \text { Debus, Juergen } & \text { (Germany) } \\ \text { Duchesne, Gillian } & \text { (Australia) } \\ \text { Durante, Marco } & \text { (Germany) } \\ \text { Giaccia, Amato J. } & \text { (USA) } \\ \text { Gueulette, John } & \text { (Bergiam) } \\ \text { Hei, Tom K. } & \text { (USA) } \\ \text { Kataoka, Yasushi } & \text { (USA) }\end{array}$

Kiefer, Julgen

Komaki, Ritsuko

Kronenberg, Amy

Lavin, Martin F.

Le Sech, Claude

Loeffle, Jay Steven

Morgan, William F.

Mullenders, Leon

(The Netherlands)

Nair, C. K. Krishnan (India)

Potter, Richard

(Austria)

(Germany)

(USA)

(USA)

(Australia)

(France)

(USA)

(USA)
(USA)

(USA) 


\section{Journal of Radiation Research Instruction for Authors}

Jan., 2010

\section{General}

Journal of Radiation Research (JRR) is an official journal of The Japan Radiation Research Society (JRRS), and the Japanese Society for Therapeutic Radiology and Oncology (JASTRO). This journal covers all fields in life sciences and medical sciences concerning with radiation, such as Biology, Chemistry, Environmentology, Epidemiology, Oncology, Physics, Radiology, and so on. All articles is covered in the Current Contents and Science Citation Index, cited in ChemPort, CrossRef, GoogleScholar, PubMed, and other major search site in the world, and released on web at J-STAGE as an open access journal. The members and non-members are encouraged to submit English MS that analyzed and discussed based on the experimental results and evidences with methods in natural sciences. Clinical case reports are not acceptable. Publication is supported by JRRS and JASTRO societies.

\section{Code of Ethics}

Authors are required to follow the ethical procedures in their countries when human or animal subjects are involved in their research. In the case of studies involving human subjects, the authors should assure in the MS either that the study has been reviewed and approved by the ethics committee in their institution or that the anonymity of subjects are preserved. The Code of Ethics of the World Medical Association (Declaration of Helsinki) represents a minimal requirement. When experimental animals are used, the authors should assure in the MS that the studies have been reviewed and approved by the committee that oversees the ethics of research involving the use of animals and the welfare of the animals.

\section{Article Categories}

The journal publishes the following scientific article categories. But case reports are not acceptable. All MS will be peer reviewed by reviewers in selected field that appears in submission process (review fields).

(i) Regular Paper: Article of original and novel scientific studies that relating to research on radiation. The article must be a full scientific paper, and the results must be performed under experimental plan organized well. The results were also well analyzed and discussed. The MS sections must be arranged in the following order: i) Title page, ii) Abstract, iii) Introduction, iv) Materials and Methods, v) Results, vi) Discussion, vii) Acknowledgements (optional), and viii) References. Do not use "Conclusion" section. Manuscript usually consists more than 5,000 words with enough figures and/or tables to describe the results very well and discuss.

(ii) Short Communication: This category is a MS of simple and brief reports describing results obtained in selected experiments. The MS sections must be arranged as follows: i) Title page, ii) Abstract, iii) Introduction, iv) Materials and Methods, v) Results and Discussion, vi) Acknowledgements (optional), and vii) References. Do not use "Conclusion" section. Article should not exceed 5,000 words with few important figures or tables. Papers to this category may process faster than the other categories.

(iii) Technical Report: Article of this category is short scientific work that introduces novel skills dealing with new methods and techniques with a few results obtained from the methods. The sections must be arranged: i) Title page, ii) Abstract, iii) Introduction, iv) Materials and Methods, v) Results and Discussion, vi) Acknowledgements (optional), and vii) References.

(iv) Review: Reviews are usually invited, and should cover recent advances in radiation research. The sections of i) Title page, ii) Abstract, iii) Introduction, and iv) References are required. Main sections are coordinated by the author, and are inserted between Introduction and Reference sessions. Please ask to our office before submit a
MS of this category.

(v) Topical Review: The articles should be brief review of topical interests, generally references including later than the past 5 years. This review is either invited or volunteered, and should not exceed a maximum of 5,000 words. Coordination of the session is same above.

(vi) Award Article: This category is for invited articles by awardees of member society such as the Distinguished Scientist Award or the Young Investigator Award of JRRS.

(vii) Miscellaneous: We may add another categories than above listed such as Letter to Editor, Erratum, and so on.

\section{Preparation of manuscripts}

Use A4 $\left(210 \times 297 \mathrm{~mm}^{2}\right)$ format with $25 \mathrm{~mm}$ margin on all around, and use 11 points "Times New Roman" characters. Please save your MS file as (.doc) format, but not (.docx) format. Do not use language specific 2-byte characters, e.g. Chinese, Japanese, Korean, and so on. Please be careful for invisible characters such as "space", "line-feed". Each page should consist of approximately 30 lines, with consecutive page numbers starting from the first page, and line numbers without refreshing at page break to make easy to indicate the locations of sentences at comments or suggestions by reviewers. One printed page consists approximately 1,000 words without figures and tables.

Template of JRR manuscript is available. $==>$ JRRMS.doc

Manuscript file must include text body, tables and figures. Title-page include i) Title, ii) Authors name, iii) Affiliations, iv) running short title, v) 3-5 Keywords, vi) total page numbers, numbers of tables and figures, vii) information of corresponding author (phone, fax and e-mail address). We don't suggest free e-mail, because all contact during review process will performed only by e-mail, and some free mail address happens a trouble. Insert figures and tables at each approximate location in the text. If inserting those items are difficult, please indicate the locations in the text, draw/write them separately from the text but together with the caption in a page, and put them at the end of the MS. At uploading the document, merge all the pages into a single document file (.doc). Please reduce the file size enough small. Separate figures or pictures in printing quality can be uploaded when submitting final MS after acceptance.

Abstract must include purpose, materials and methods, results, and conclusion in short sentences in single paragraph within 250 words without line feeds. Do not use heading titles (such as "Purpose", "Results" and so on).

Figures and Tables should be numbered consecutively in Arabic numerals, e.g., Fig. 1, Fig. 2, or Table 1. They should be designed to fit and to be clearly visible in the printed page within single column $(\sim 8.5$ $\mathrm{cm})$ or double columns $(\sim 17.5 \mathrm{~cm})$ width. Figures in printing quality are not necessary during review process. We strongly suggest reduce the file size for reviewing and upload optional full quality figures at final MS submission. Photographs and/or figures that require a higher resolution may be asked later at printing. Heading and captions should be self-explanatory, and they are better to be written on the same page to each figure or table. Color plates are accepted but we will charge excess cost to the author.

References must be cited numerically as they appear in the text, and they must (at least the Abstract) written in English. Up to 3 authors can be listed. When the authors are more than 4 , list only the first author and put "et al.". No period and blank at abbreviated first and middle name. Use a hyphen between characters of first name that consists with two Chinese characters (e.g. Chinese or Korean). Use ISO abbreviated journal names. Typical reference forms are:

1. Tauchi H, et al (2009) Two major factors involved in the reverse dose-rate effect for somatic mutation induction are the cell cycle position and LET value. J Radiat Res 50: 441-445. 
2. Chen C-Y, Yang K-C and Pan L-K (2009) Bubble technique for evaluating effective dose of diagnostic $\mathrm{X}$-rays: a feasibility study. $\mathrm{J}$ Radiat Res 50: 449-456.

3. Furusawa Y (2003) Advantages for the use of heavy-ion irradiation on cancer cells at radiotherapy. In: Taujii $\mathrm{H}$ and Ban $\mathrm{S}$ eds. Toward the Tailor-made Radiotherapy. pp. 85-90. Jitsugyou-Kouhou-Sha; Tokyo. (in Japanese)

4. Horsman MR and Overgaard J (2002) The oxygen effects and tumor microenvironment. In: Steel GG ed. Basic Clinical Radiobiology. 3rd ed. pp.158-168, Hodder Arnold; London.

5. IAEA (2008) Biological weighting of absorbed dose: The specific issue of RBE in ion beam therapy. In: Relative Biological Effectiveness in Ion Beam Therapy. TRS 461. pp.8-25. International Atomic Energy Agency, Vienna.

6. ICRP (1991) 1990 Recommendations of the International Commission on Radiological Protection, ICRP Publication 60, Annals of the ICRP, Vol. 21, Pergamon Press, Oxford.

\section{Submission on Web}

All MS must be submitted through the WEB contribution system. This system is used for all processes throughout the MS submission, reviewing, and publication.

Upload your MS produced by Microsoft Word ${ }^{\mathrm{R}}$ (.doc) together with a PDF (.pdf) file by the Adobe Acrobat ${ }^{R}$ as backup. We strongly suggest submitting both files, and each file must including all text, tables, and figures. Animated or fine pictures, sounds, big tables or computer codes that may be useful but not suitable to print can be published as electric appendix only on web version of the journal.

Process of submitting manuscript is as follows. You will fill 9 pages on web, do not use a 2-byte character, and refer HTML tags that linked from the submission pages when special characters or effects (symbols, italics, super- or sub-scripts, and so on) are required. REMEMBE your ID number that will be shown on the 9th page and password that you enter in the submission process for each MS, because they are required at father review processes.

Author and Manuscript Information: (page 1/9)

Reviewing Category: Select MS type and Review field(s) from pull-down menu.

Title: Title not exceeding 40 words, and Running short title not exceeding 50 characters.

Abstract: Single paragraph without line feeds, within 250 words.

Manuscript: English style of the MS must be edit by a native speaker before submitting final MS. Name and contact of the editor/company will be asked, it you are not native.

Corresponding Author: Responsible for the MS, and contact person throughout reviewing.

Miscellaneous: We consider that the author agree all the statements concerning the compliance in this "Instruction for Authors", when you have marked "Yes" in "Compliance in Introduction".

List of Affiliations and Authors: (page 2/9 and 3/9)

List all the author's information, nor the names may not appear in the paper. Affiliations should be ordered that author appears. First Name of authors must written in small characters except for the first character, and LAST NAME must be written all in capitals. Use [more] button to increase the inbox.

Upload Manuscript Files: (page 4/9)

Manuscript File: Produce a MS including all figures and tables in one file. A Microsoft Word ${ }^{\mathrm{R}}$ file of quality for reviewing, and the size up to $4 \mathrm{MB}$ can be uploaded. (You can upload fine figures with printing quality at submission of the final MS.)

Backup File: A PDF file up to 4 MB.

Suggested and Exclude Reviewers: (page 5/9 and 6/9)

Suggest reviewers (requires the Name, Affiliation, Phone number, and e-mail address) and exclude reviewers.
Edit Data: (page 7/9)

Please confirm and edit data you entered.

Confirm Data: (page 8/9)

Once author submitted the MS, it is no longer possible to modify it. When find some mistake, please click "back" to go to previous page to edit it.

Information: (page 9/9)

You will be informed Temporary Receipt Number in the final page of the submission process.

Contributor Menu

You can visit your page with ID (temporary/actual receipt ID) and Password at submission.

\section{Page Charge and Reprints:}

We will ask page-charge JPY 5,000 per one printed page and excess color charge (JPY 30,000 per one color page) to all authors. JRR is supported by JRRS and JASTRO, and we will charge JPY 10,000 for each manuscript submitted by the author who is not the member. All the charges will be asked at proof reading. For members (JRRS or JASTRO), 30 non-covered reprints will be sent to the author free, and page charge will be reduced. The reduction rate corresponds to the duration of the membership i.e. each $10 \%$ for every year up to $50 \%$, after the 2nd year of the membership at submission of the manuscript. Price for excess reprints are listed in the table below.

\begin{tabular}{|c|c|c|c|c|c|c|c|}
\hline & $\begin{array}{l}\text { copies } \\
\text { pages }\end{array}$ & 50 & 100 & 150 & 200 & 250 & 300 \\
\hline \multirow{5}{*}{$\begin{array}{l}\text { Basic fee for } \\
\text { reprints } \\
\text { (w/o cover) }\end{array}$} & $1-4$ & $¥ 6,500$ & $¥ 12,000$ & $¥ 16,500$ & $¥ 20,000$ & $¥ 22,500$ & $¥ 24,000$ \\
\hline & $5-8$ & $¥ 9,000$ & $¥ 17,000$ & $¥ 24,000$ & $¥ 30,000$ & $¥ 35,000$ & $¥ 39,000$ \\
\hline & $9-12$ & $¥ 11,500$ & $¥ 22,000$ & $¥ 31,500$ & $¥ 40,000$ & $¥ 47,500$ & $¥ 54,000$ \\
\hline & $13-16$ & $¥ 14,000$ & $¥ 27,000$ & $¥ 39,000$ & $¥ 50,000$ & $¥ 60,000$ & $¥ 69,000$ \\
\hline & $17-20$ & $¥ 16,500$ & $¥ 32,000$ & $¥ 46,500$ & $¥ 60,000$ & $¥ 72,500$ & $¥ 84,000$ \\
\hline \multicolumn{2}{|c|}{ Surcharge for cover } & $¥ 7,000$ & $¥ 7,500$ & $¥ 8,000$ & $¥ 8,500$ & $¥ 9,000$ & $¥ 9,500$ \\
\hline
\end{tabular}

\section{Compliance:}

The JRR adheres to the policy on conflict of interest promulgated by the International Committee of Medical Journal Editors, which states, in part, that "to prevent ambiguity, authors must state explicitly whether potential conflicts do or do not exist." Following agreements considered to be done in the process of MS submission (by checking "yes" at "Compliance of Instruction").

1. This manuscript is original, has not already been published, and is not currently under consideration by another journal.

2. All the authors and the institutions where the work has carried out have approved submission of this manuscript.

3. Authors agree to the ethical procedures in their countries when human or animal subjects are involved in their research.

4. Copyright, right of publication, right of reproduction and public token of the article published in the JRR will lies with the Editorial Committee of Journal of Radiation Research.

5. The author will pay the page charge and reprint fee as informed at proofreading (see below).

(Note: We will not publish articles or not receive manuscripts for 3 years when the authors contravene this compliance.)

\section{Contact:}

Editorial Office, Journal of Radiation Research

c/o Medical Supply Japan Co., Ltd.

Natsume Bldg 3F, 2-18-6, Yushima Bunkyo-ku,

Tokyo, 113-0034, Japan

Tel; +81-3-3818-2176, Fax; +81-3-3818-2209

E-mail; jrroffice@nirs.go.jp / /jrred@me.com 


\section{Acknowledgement}

The members of the Japanese Radiation Research Society sincerely express our gratitude to the following corporations and organizations for their contributions as supporting members. We appreciate the co-operation and kindness shown and look forward to working together in the future.

ALOKA CO., LTD.

CENTRAL RESEARCH INSTITUTE OF ELECTRIC POWER INDUSTRY

CHUBU ELECTRIC POWER CO., INC.

THE CHUGOKU ELECTRIC POWER CO., INC.

HEALTH RESEARCH FOUNDATION

HOKKAIDO ELECTRIC POWER CO., INC.

HOKURIKU ELECTRIC POWER COMPANY

IKEDA SCIENTIFIC CO., LTD.

INSTITUTE FOR ENVIRONMENTAL SCIENCES

INSTITUTE OF RADIATION MEASUREMENTS

JAPAN ATOMIC ENERGY AGENCY Intellectual Resource Department

JAPAN ATOMIC ENERGY AGENCY Safety Administration Department

JAPAN ATOMIC ENERGY RELATIONS ORGANZATION

JAPAN ATOMIC INDUSTRIAL FORUM, INC.

THE JAPAN ATOMIC POWER COMPANY

JAPAN CHEMICAL ANALYSIS CENTER

JAPAN NUCLEAR FUEL LIMITED

JAPAN RADIOISOTOPE ASSOCIATION

THE KANSAI ELECTRIC POWER CO., INC.

KYUSHU ELECTRIC POWER CO., INC.

NATIONAL INSTITUTE OF RADIOLOGICAL SCIENCES

NUCLEAR SAFETY RESEARCH ASSOCIATION

RADIATION EFFECTS ASSOCIATION

RADIATION EFFECTS RESEARCH FOUNDATION

SANGYO KAGAKU CO., LTD.

SHIKOKU ELECTRIC POWER CO., INC.

TOHOKU ELECTRIC POWER CO., INC.

TOKYO ELECTRIC POWER COMPANY

TOKYO NUCLEAR SERVICES CO., LTD.

(Alphabetical Order)

This issue is partly supported by Grant-in-Aid for Publication of Scientific Research Results by Japan Society for the Promotion of Sciences (JSPS) 


\section{お客さまに信頼される研究パートナーとして、 池田理化は確かなサポートをお約束いたします。}

池田理化は研究者の方々に最先端の機器や情報をお届けする理化学機器の専門商社です。 1931 年の創業以来、長きにわたり培った経験と情報を味方に、質の高い製品とサービスを提供します。 関東を中心に 13 ヶ所の営業拠点を設置し、お客さまの近くからきめ細やかなサービスを実現しています。

\section{0}

\section{森式会社池田理化}

http://www.ikedarika.co.jp
本社東京都千代田区鍛冶町 1-8-6神田KSビルテ101-0044

TEL 03-5256-1811 FAX 03-5256-1818 岩本町別館・八王子·鶴見・横浜·平塚・千葉·埼玉·つくば・宇都宮·三島・藤枝·大阪 池田理化 shop 楽天市場店ｈttp://www.rakuten.co.jp/ikedarikashop/

Journal of Radiation Research Vol. 51 No. 3

An official journal of The Japan Radiation Research Society and

Japanese Society for Therapeutic Radiology and Oncology

$\begin{array}{ll}\text { Date of Issue } & \text { May 16, 2010 } \\ \text { Editor-in-Chief } & \text { Yoshiya FURUSAWA } \\ \text { Editor-in-Vice-Chief } & \text { Takashi NAKANO } \\ \text { Publisher } & \text { JRR Editorial Committee } \\ \text { Editorial Office } & \text { c/o Medical Supply Japan Co., Ltd. } \\ & \text { Natsume Bldg 3F, 2-18-6, Yushima Bunkyo-ku, } \\ & \text { Tokyo, 113-0034, Japan } \\ & \text { Tel; +81-3-3818-2176, Fax; +81-3-3818-2209 } \\ \text { Printer } & \text { Letterpress Co., Ltd. }\end{array}$

Browsing; http://www.jstage.jst.go.jp/browse/jrr

Contribution; http://ess.jstage.jst.go.jp/contrib/JRR/initialsubmission

Print ISSN: 0449-3060 Online ISSN: 1349-9157

Copyright (C) 2010 by The Japan Radiation Research Editorial Committee 


\section{JOURNAL OF RADIATION RESEARCH}

Vol. 51, No. 3, May 2010

Review

223 Studies on Biological Effects of Ion Beams on Lethality, Molecular Nature of Mutation, Mutation Rate, and Spectrum of Mutation Phenotype for Mutation Breeding in Higher Plants

Tanaka A, Shikazono $N$ and Hase $Y$

Regular Papers

235 Cytogenetic Effects of Low Doses of Energetic Carbon Ions on Rice After Exposures of Dry Seeds, Wet Seeds and Seedlings

Shi JM, Guo JG, Li WJ, Zhang M, Huang L and Sun YQ

243 Cytogenetic and Molecular Characterization of Plutonium-Induced Rat Osteosarcomas

Roch-Lefevre S, Daino K, Altmeyer-Morel S, Guilly MN and Chevillard S

251 AT Cells Show Dissimilar Hypersensitivity to Heavy-Ion and X-rays Irradiation

Kitajima S, Nakamura H, Adachi M, Ijichi K, Yasui Y, Saito N, Suzuki M, Kurita K and Ishizaki K

257 HDAC Inhibitor-Mediated Radiosensitization in Human Carcinoma Cells: A General Phenomenon?

Kim IA, Kim IH, Kim HJ, Chie EK and Kim JS

265 Circadian Transitions in Radiation Dose-Dependent Augmentation of mRNA Levels for DNA Damageinduced Genes Elicited by Accurate real-time RT-PCR Quantification

Ishihara H, Tanaka I, Yakumaru H, Chikamori M, Ishihara F, Tanaka M, Ishiwata A, Kurematsu A, Satoh A, Ueda J and Akashi M

277 2-GHz Band CW and W-CDMA Modulated Radiofrequency Fields Have No Significant Effect on Cell Proliferation and Gene Expression Profile in Human Cells

Sekijima M, Takeda H, Yasunaga K, Sakuma N, Hirose H, Nojima T and Miyakoshi J

285 Myricetin Inhibits Akt Survival Signaling and Induces Bad-mediated Apoptosis in a Low Dose Ultraviolet (UV)-B-irradiated HaCaT Human Immortalized Keratinocytes

Kim W, Yang HJ, Youn H, Yun YJ, Seong KM and Youn B

297 The Modified High-Density Survival Assay is the Useful Tool to Predict the Effectiveness of Fractionated Radiation Exposure

Kuwahara Y, Mori M, Oikawa T, Shimura T, Ohtake Y, Mori S, Ohkubo Y and Fukumoto M

303 Radiation-induced XRCC4 Association with Chromatin DNA Analyzed by Biochemical Fractionation

Kamdar RP and Matsumoto $Y$

315 Induction of Micronuclei in Germinating Onion Seed Root Tip Cells Irradiated with High Energy Heavy lons Takatsuji T, Takayanagi H, Morishita K, Nojima K, Furusawa Y, Nakazawa Y, Matsuse M, Akamatsu S, Hirano N, Hirashima N, Hotokezaka S, Ijichi T, Kakimoto C, Kanemaru T, Koshitake M, Moriuchi A, Yamamoto $K$ and Yoshikawa I

325 Protective Effect of Urinary Trypsin Inhibitor on the Development of Radiation-Induced Lung Fibrosis in Mice

Katoh H, Ishikawa H, Hasegawa M, Yoshida Y, Suzuki Y, Ohno T, Takahashi T and Nakano T

333 Outcome of Stereotactic Radiosurgery for Patients with Non-Small Cell Lung Cancer Metastatic to The Brain

Mariya Y, Sekizawa G, Matsuoka Y, Seki H and Sugawara T

343 Higher pAkt Expression Predicts a Significant Worse Prognosis in Glioblastomas

Suzuki Y, Shirai K, Oka K, Mobaraki A, Yoshida Y, Noda S, Okamoto M, Suzuki Y, Itoh J, Itoh H, Ishiuchi $S$ and Nakano T

Short Communication

349 Low-Dose Gamma-Ray Irradiation Induces Translocation of Nrf2 Into Nuclear in Mouse Macrophage RAW264.7 Cells

Tsukimoto M, Tamaishi N, Homma T and Kojima $S$ 